Sharif University of Technology
Scientia Iranica
SCIENTIA
I RAN I CA

\title{
Influence of foundation flexibility on the seismic response of low-to-mid-rise moment-resisting frame buildings
}

\author{
H. Tahghighi* and M. Rabiee \\ Department of Civil Engineering, University of Kashan, Kashan, P.O. Box 87317-51167, Iran.
}

Received 24 October 2015; received in revised form 25 January 2016; accepted 13 February 2016

KEYWORDS
Seismic response;
Soil-structure
interaction;
Moment-resisting
frame;
Nonlinear analysis;
Design code.

\section{Introduction}

The dynamic response of a structure to earthquake excitation can significantly be affected by interactions between three linked systems: the structure, the foundation, and the soil underlying and surrounding the foundation. In reality, the supporting soil somewhat influences the structural response by permitting movement due to its natural ability to deform. SoilStructure Interaction (SSI) analysis evaluates the collective response of these systems to a specified freefield ground motion. When the ground is stiff enough, the dynamic response of the structure will not be influenced significantly by the soil properties during

\footnotetext{
*. Corresponding author. Tel.: +983155912430;

Fax.: +983155912424

E-mail addresses: tahghighi@kashanu.ac.ir (H. Tahghighi);

kashan.civil@gmail.com (M. Rabiee)
}

the earthquake, and the structure can be analyzed under the fixed-base condition. But, for the structure resting on a flexible medium, the dynamic response of the structure will be different from that of the fixedbase condition, owing to the interaction between the soil and the structure [1]. In the case of a flexible-base structure, in addition to the added rocking component to the horizontal motion of the structure, a part of the structure's vibrating energy will be transmitted to the soil layer, and it can be dissipated due to radiation damping resulting from the wave propagation and hysteresis damping of the soil materials.

In general, SSI effects can be summarized as follows: reduction of the natural frequency of the system, increase in damping, increase in the rate of the lateral displacement, and change in the force demands of the structure [2,3]. For stiff structural systems, such as shear wall and braced frame founded on soil, ignoring the influence of foundation movements could 
lead to significant misestimation of the fundamental frequency in the system [4-6]. Analyses conducted under various soil and structure conditions showed that this influence depends mainly on the soil-structure relative rigidity. The increased period and damping of the soil-structure system largely lead to the consequences and the beneficial effects the SSI has, which are mostly ignored in seismic design of buildings. This conclusion could be misleading, since ignoring base flexibility may over-or under-predict seismic response of the structure depending primarily on the characteristics of the ground motions. It was shown that the SSI can play a detrimental role in producing such influences, and neglecting its influence could lead to an unsafe design $[7,8]$. According to more recent findings, neglecting the effects of SSI on seismic performance of rocking structures with shallow foundations may drastically bias the estimation of force demands against near-fault pulse, such as ground motions [9]. Therefore, it is recommended to take the nonlinear SSI effects into consideration in order to avoid rough estimation of structural seismic demands.

Although not widely used in practice, engineering guidelines are available for simple evaluation of SSI effects. Recent code-compliant seismic designs for SSI systems, such as NEHRP [10] and ASCE 7 [11], are based on the approximation to which the predominant period and associated damping of the corresponding fixed-base system are modified. On the other hand, ATC 40 [12] and FEMA 356 [13] partially address the effects of flexible foundation through inclusion of the stiffness and strength of the soil components of the foundation (Winkler-based model) on the structural analysis. However, none of these procedures addresses the shaking demand on the structure relative to the free-field motion caused by kinematic interaction or the foundation damping effect. Guidelines on the inclusion of the effects of kinematic interaction are given in FEMA 440 [14] and ASCE 41 [15]. The Ratio of Response Spectra (RRS) factor is used to represent kinematic interaction effects in these codes. RRS is simply the ratio of the response spectral ordinates imposed on the foundation (i.e., the foundation input motion) to the free-field spectral ordinates. It is noteworthy to mention that the kinematic effects are usually most pronounced in short periods, and hence are unlikely to significantly affect responses of buildings within a fundamental period greater than approximately $1 \mathrm{sec}[6,16]$.

SSI, particularly for superstructures resting on relatively soft soils, may significantly amplify the lateral displacements and inter-storey drifts $[17,18]$. The amplification of lateral deformations may change the performance level of the building frames while subjected to earthquakes. Tabatabaiefar et al. [18] investigated the accuracy of nonlinear method against equivalent linear method for dynamic analysis of SSI, using shaking table tests. They concluded that the results obtained from the fully nonlinear method of analysis fit the experimental results reasonably well, but the equivalent linear method underestimates the inelastic seismic response of mid-rise moment-resisting building frames resting on soft soils. Therefore, the fully nonlinear method was recommended by practicing engineers to be used.

Various numerical methods were used to model the behaviour of structures on shallow foundations [1922]. However, the application of simple methods, such as the Winkler approach, is preferred in practical SSI problems. In this context, Beam-on-NonlinearWinkler-Foundation (BNWF) method, proposed by Harden et al. [23], Harden and Hutchinson [24], and later by Gajan et al. [25], has been widely applied in recent studies due to its relative simplicity and minimal computational effort (e.g. $[9,26,27]$ ). The present article attempts to cover a wide range of interaction problems in terms of the superstructure, the soil characteristics, and the seismic excitation intensities in which the BNWF method is used to model the behavior of shallow foundation. To do so, an extensive parametric study, including different approaches of analysis along with various soil and structure conditions, is carried out to evaluate seismic response of low-to-midrise steel Moment Resisting Frame (MRF) buildings subjected to earthquake motions of different hazard levels. The numerical results indicate that the SSI which is significantly important to the performancebased design of structures can alter the force and drift demands.

\section{Structural and geotechnical description of the models}

A set of 4-, 8-, 12-, and 16-storey steel MRFs located on hypothetically soft, medium, and hard sites is considered. The building models have a floor plan of $18.0 \times 18.0 \mathrm{~m}$, three bays each having a horizontal direction at intervals of $6.0 \mathrm{~m}$, a uniform mass distribution over their height, and a non-uniform stiffness distribution (Figure 1). The storey height of the models was considered as $3.3 \mathrm{~m}$; a normal height for residential buildings. These models represent a large number of conventional low-to-mid-rise buildings in mega cities at relatively high-risk earthquake-prone countries, such as Iran. Buildings were designed as special frames based on the requirement of Iranian national building codes [28,29] and Iranian code of practice for seismic resistant design of buildings (Standard No. 2800) [30]. The dead and live loads of 600 and $200 \mathrm{kgf} / \mathrm{m}^{2}$, respectively, were used for gravity loads. Consequently, the self-weight of $306720,643960,982530$, and $1334880 \mathrm{~kg}$ were obtained for 4-, 8-, 12-, and 16-storey frames, 


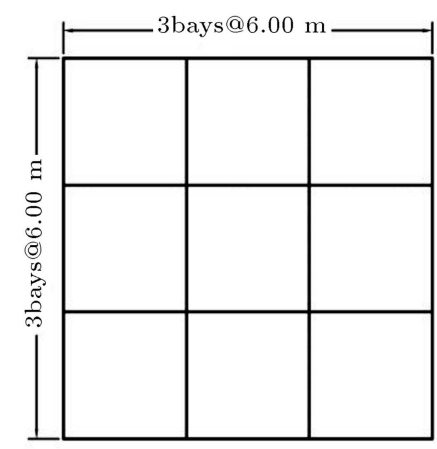

(a)
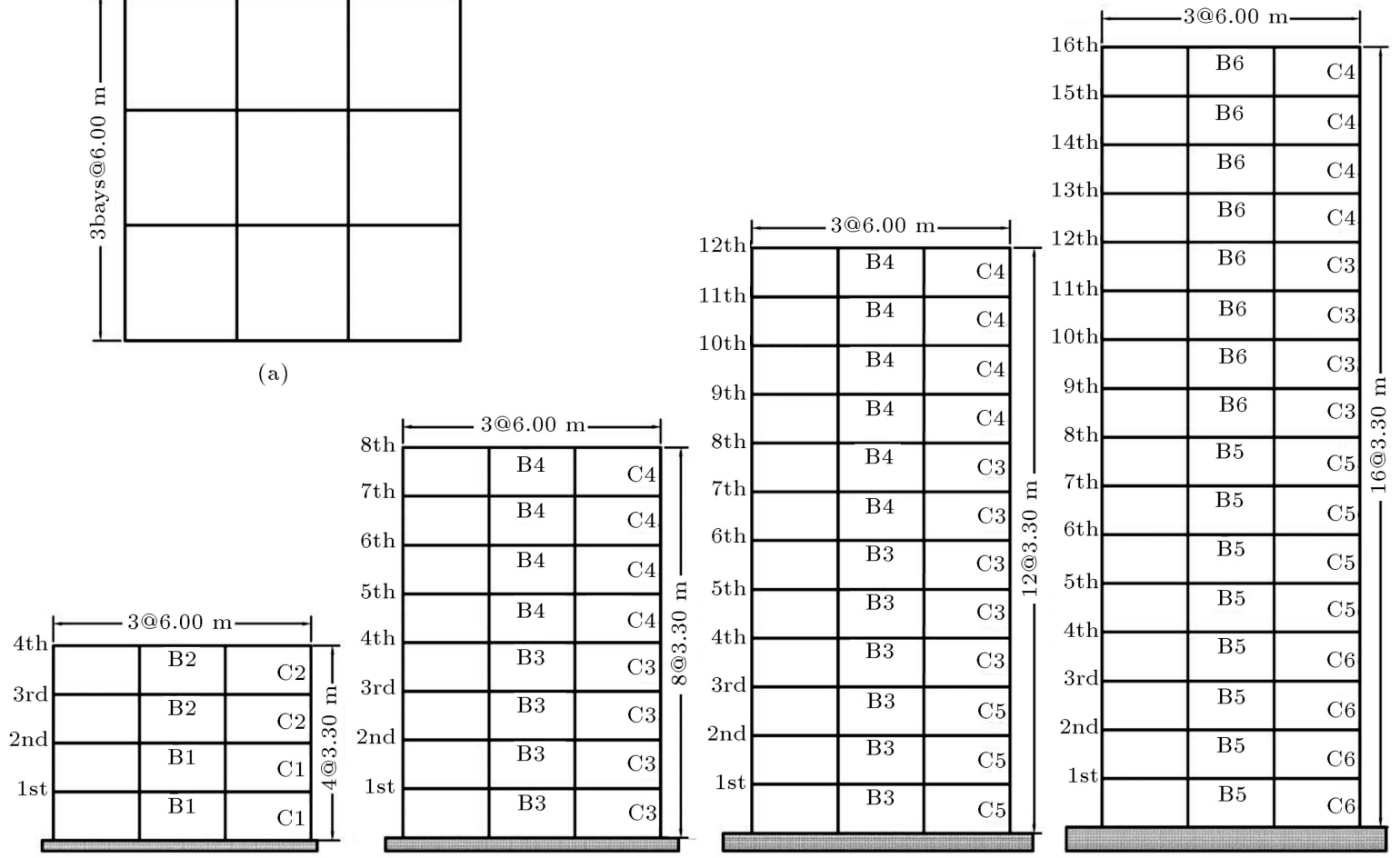

(b)

Figure 1. Configuration of building models: (a) Plan and (b) elevation.

respectively. In regard to the frames' design, the importance factor of $I=1$, response modification factor of $R=7.5$, and seismic zone factor of $A=0.30$ were considered. In this paper, the steel type St-37 was used for the structural beam and column members. Table 1 lists the details of utilized I-beam sections for the MRF models shown in Figure 1.

Columns are supported by strip footings which rest on different soil conditions including types II $\left(375<V_{s}<750 \mathrm{~m} / \mathrm{s}\right)$, III $\left(175<V_{s}<375 \mathrm{~m} / \mathrm{s}\right)$, and IV $\left(V_{s}<175 \mathrm{~m} / \mathrm{s}\right)$ according to the classification of the Standard No. 2800. It is worthy to note that for soils with shear wave velocity greater than $600 \mathrm{~m} / \mathrm{s}$, the effect of SSI is not considerable [20,31]. The details of various soil parameters are as those tabulated in Table 2, extracted from the actual geotechnical projects $[32,33]$. The material properties used in the reinforced concrete foundation design are modulus of elasticity $E_{c}=2.19 \times 10^{5} \mathrm{kgf} / \mathrm{cm}^{2}$, compressive strength $f_{c}=210 \mathrm{kgf} / \mathrm{cm}^{2}$, Poisson ratio $v=0.2$ for concrete, and yield strength $f_{y}=4000 \mathrm{kgf} / \mathrm{cm}^{2}$ for steel. Table 3 summarizes the characteristics of the footings in this study, where $q_{a l l}$ is allowable bearing capacity of soil, $K_{s}$ is the subgrade soil reaction.

Table 1. Details of steel I-beam sections.

\begin{tabular}{cccccc}
\hline Section tag & \multicolumn{3}{c}{ Web } & & \multicolumn{2}{c}{ Flange } \\
\cline { 2 - 3 } \cline { 5 - 6 } & Depth $\mathbf{( c m})$ & Thickness $\mathbf{( c m )}$ & & Width $\mathbf{( c m )}$ & Thickness (cm) \\
\hline C1 & 31.95 & 2.11 & 39.88 & 3.33 \\
C2 & 32.10 & 1.64 & & 37.34 & 2.62 \\
C3 & 44.40 & 2.00 & & 50.00 & 2.80 \\
C4 & 35.60 & 2.00 & & 40.00 & 2.20 \\
C5 & 53.40 & 2.50 & & 60.00 & 3.30 \\
C6 & 62.00 & 3.00 & & 70.00 & 4.00 \\
B1 & 27.84 & 1.09 & & 30.48 & 1.70 \\
B2 & 27.65 & 0.99 & & 30.48 & 1.54 \\
B3 & 38.18 & 1.49 & & 26.42 & 2.50 \\
B4 & 38.23 & 1.33 & & 26.42 & 2.22 \\
B5 & 50.09 & 1.16 & & 21.08 & 1.88 \\
B6 & 50.11 & 1.09 & & 21.01 & 1.74 \\
\hline
\end{tabular}


Table 2. Details of soil parameters.

\begin{tabular}{ccccccc}
\hline Soil type & $\boldsymbol{\phi}(\mathbf{d e g r e e})$ & $\boldsymbol{C}\left(\mathbf{k g f} / \mathbf{c m}^{\mathbf{2}}\right)$ & $\boldsymbol{v}$ & $\boldsymbol{\gamma}\left(\mathbf{k g f} / \mathbf{m}^{\mathbf{3}}\right)$ & $\boldsymbol{G}\left(\mathbf{k g f} / \mathbf{c m}^{\mathbf{2}}\right)$ & $\boldsymbol{V}_{\boldsymbol{S}}(\mathbf{m} / \mathbf{s e c})$ \\
\hline II & 30 & 0.15 & 0.35 & 2100 & 6707 & 560 \\
III & 27 & 0.10 & 0.40 & 1900 & 732.2 & 275 \\
IV & 15 & 0.03 & 0.40 & 1700 & 339.3 & 150 \\
\hline
\end{tabular}

Table 3. Foundation characteristics used in analyses.

\begin{tabular}{cccccccc}
\hline Building model & Soil type & Footing type & $\boldsymbol{B}(\mathbf{m})$ & $\boldsymbol{L}(\mathbf{m})$ & $\boldsymbol{H} \mathbf{( m )}$ & $\boldsymbol{q}_{\text {all }}\left(\mathbf{k g f} / \mathbf{c m}^{\mathbf{2}}\right)$ & $\boldsymbol{K}_{\boldsymbol{s}}\left(\mathbf{k g f} / \mathbf{c m}^{\mathbf{3}}\right)$ \\
\hline \multirow{3}{*}{ 4-storey } & II & Strip & 1.00 & 19.00 & 0.65 & 2.00 & 2.40 \\
& III & Strip & 1.20 & 19.20 & 0.65 & 1.50 & 2.00 \\
& IV & Strip & 1.50 & 19.50 & 0.65 & 1.00 & 1.50 \\
\hline \multirow{3}{*}{ 8-storey } & II & Strip & 1.70 & 19.70 & 0.90 & 2.00 & 2.40 \\
& III & Strip & 2.20 & 20.20 & 0.90 & 1.50 & 2.00 \\
& IV & Strip & 2.80 & 20.80 & 0.90 & 1.00 & 1.50 \\
\hline \multirow{2}{*}{ 12-storey } & II & Strip & 2.60 & 20.60 & 1.20 & 2.00 & 2.40 \\
& III & Strip & 3.30 & 21.30 & 1.20 & 1.50 & 2.00 \\
& IV & Strip & 4.00 & 22.00 & 1.20 & 1.00 & 1.50 \\
\hline \multirow{2}{*}{ 16-storey } & II & Strip & 3.50 & 21.50 & 1.50 & 2.00 & 2.40 \\
& III & Strip & 4.50 & 22.50 & 1.50 & 1.50 & 2.00 \\
& IV & Strip & 5.00 & 23.00 & 1.50 & 1.00 & 1.50 \\
\hline
\end{tabular}

Table 4. Ground motions selected in the present study [34].

\begin{tabular}{|c|c|c|c|c|c|c|c|c|c|c|}
\hline No. & Earthquake & Year & Station & $M_{w}^{\mathrm{a}}$ & $\begin{array}{l}\text { Soil } \\
\text { type }\end{array}$ & $\begin{array}{c}d^{\mathrm{b}} \\
(\mathrm{km})\end{array}$ & $\begin{array}{c}\text { PGA }^{\mathrm{c}} \\
(\mathrm{g})\end{array}$ & $\begin{array}{l}P_{G V}{ }^{d} \\
(\mathrm{~cm} / \mathrm{s})\end{array}$ & $\begin{array}{c}P G^{e} \\
(\mathrm{~cm})\end{array}$ & $\begin{array}{c}T_{0}{ }^{f} \\
(\mathrm{sec})\end{array}$ \\
\hline 1 & Northridge, USA & 1994 & Old Ridge Route & 6.7 & II & 22.6 & 0.57 & 52.1 & 4.2 & 0.26 \\
\hline 2 & Cape Mendocino, USA & 1992 & Rio Dell Overpass & 7.1 & II & 18.5 & 0.55 & 42.1 & 18.6 & 0.42 \\
\hline 3 & Chi-Chi, Taiwan & 1999 & TCU045 & 7.6 & II & 24.0 & 0.51 & 39.0 & 14.3 & 0.40 \\
\hline 4 & Loma Prieta, USA & 1989 & Gilroy Gavilan Coll. & 6.9 & II & 12.0 & 0.36 & 28.6 & 6.3 & 0.40 \\
\hline 5 & San Fernando, USA & 1971 & Lake Hughes & 6.6 & II & 20.3 & 0.37 & 17.0 & 1.6 & 0.16 \\
\hline 6 & Victoria, Mexico & 1980 & Cerro Prieto & 6.1 & II & 17.0 & 0.62 & 31.6 & 13.2 & 0.06 \\
\hline 7 & Whittier Narrows, USA & 1987 & LA-116th St School & 6.0 & II & 22.5 & 0.39 & 21.0 & 1.8 & 0.14 \\
\hline 8 & Chuetsu-Oki, Japan & 2007 & Kashiwazaki NPP & 6.8 & III & 11.0 & 0.45 & 125 & 49.8 & 1.90 \\
\hline 9 & El Mayor-Cucapah, USA & 2010 & RIITO & 7.2 & III & 13.7 & 0.39 & 52.4 & 50.5 & 0.12 \\
\hline 10 & El Mayor-Cucapah, USA & 1987 & Cerro Prieto & 7.2 & III & 11.0 & 0.29 & 49.5 & 40.8 & 0.44 \\
\hline 11 & El Mayor-Cucapah, USA & 1987 & Michoacan & 7.2 & III & 16.0 & 0.54 & 61.6 & 34.6 & 0.24 \\
\hline 12 & Loma Prieta, USA & 1989 & Gilroy Array \#4 & 6.9 & III & 14.5 & 0.42 & 40.2 & 8 & 0.44 \\
\hline 13 & Morgan Hill, USA & 1984 & Gilroy Array \#4 & 6.2 & III & 12.0 & 0.35 & 17.3 & 3.4 & 0.24 \\
\hline 14 & Northwest China & 1997 & Jiashi & 6.1 & III & 18.0 & 0.3 & 19.3 & 3.1 & 0.20 \\
\hline 15 & Darfield, New Zealand & 2010 & Cristchurch Res. & 7.0 & IV & 19.5 & 0.27 & 62.2 & 54.9 & 0.54 \\
\hline 16 & Iwate, Japan & 2008 & MYG006 & 6.9 & IV & 30.4 & 0.24 & 41 & 24 & 0.72 \\
\hline 17 & Tottori, Japan & 2000 & SMN002 & 6. & IV & 16.6 & 0.18 & 22 & 12 & 0.98 \\
\hline 18 & Loma Prieta, USA & 1989 & Redwood City & 6.9 & IV & 48.0 & 0.28 & 53.6 & 12.7 & 1.06 \\
\hline 19 & Loma Prieta, USA & 1989 & Foster City & 6.9 & IV & 43.0 & 0.30 & 37.2 & 12.0 & 0.66 \\
\hline 20 & Superstition Hills, USA & 1987 & EL Centro Imp. & 6.5 & IV & 18.2 & 0.36 & 45.0 & 18.1 & 0.22 \\
\hline 21 & Westmorland, USA & 1981 & Westmorland Fire & 5.9 & IV & 11.0 & 0.37 & 41.0 & 11.0 & 0.59 \\
\hline
\end{tabular}

$B, L$, and $H$ are the width, length, and thickness of foundation, respectively. Factor of safety against vertical bearing failure in the absence of lateral loads was also considered nearly three, which is reasonable for realistic structures.

\section{Earthquake ground motions}

A database of 21 recorded ground motion time histories with a wide range of intensity, duration, frequency contents, and earthquake magnitudes (i.e., Mw 5.97.6) was compiled from well-known studied seismic events. All motions, recorded at closest fault distances greater than $10 \mathrm{~km}$, are divided into three groups of stiff, medium, and soft soil sites. Each soil type is represented by an ensemble of seven ground motions taken from the PEER NGA database [34]. Table 4 lists the characteristics of interest for the selected site 
Table 5. Scale factors computed for four buildings and for three sets of seven ground motions.

\begin{tabular}{ccccccc}
\hline \multirow{2}{*}{ No. } & Hazard level & Soil type & \multicolumn{4}{c}{ Scale factor } \\
\cline { 4 - 6 } & & & 4-storey & 8-storey & 12-storey & 16-storey \\
\hline 1 & $50 \%$ in 50 years & II & 0.70 & 0.57 & 0.66 & 0.95 \\
2 & $10 \%$ in 50 years & II & 1.61 & 1.31 & 1.51 & 2.18 \\
3 & $2 \%$ in 50 years & II & 2.41 & 1.96 & 2.27 & 3.27 \\
\hline 4 & $50 \%$ in 50 years & III & 0.89 & 0.89 & 0.89 & 0.89 \\
5 & $10 \%$ in 50 years & III & 2.04 & 2.04 & 2.04 & 2.04 \\
6 & $2 \%$ in 50 years & III & 3.06 & 3.06 & 3.06 & 3.06 \\
\hline 7 & $50 \%$ in 50 years & IV & 0.64 & 0.60 & 0.94 & 1.17 \\
8 & $10 \%$ in 50 years & IV & 1.47 & 1.38 & 2.15 & 2.67 \\
9 & $2 \%$ in 50 years & IV & 2.21 & 2.07 & 3.22 & 4.01 \\
\hline
\end{tabular}

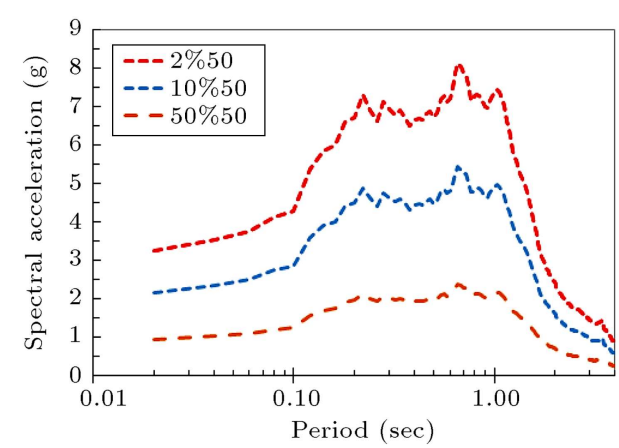

(a)

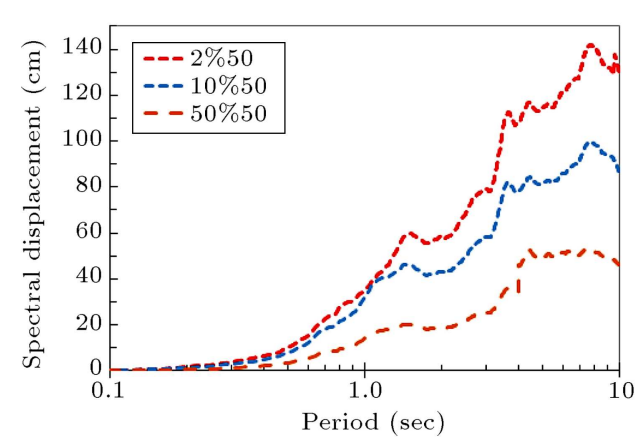

(b)

Figure 2. (a) Mean acceleration response spectra, and (b) mean displacement response spectra for $5 \%$ damped elastic systems. Comparisons are plotted for three hazard levels at soil type IV scaled for 12-storey model.

and structure-specific ground motion records. More details of these motions can be found in [35]. The earthquake records were separately scaled according to the procedures described in Iranian Standard No. 2800 at seismic hazard levels of probability of exceedance of $50 \%, 10 \%$, and $2 \%$ in 50 years. Table 5 lists the scaled factors computed for each set of seven ground motions of each building. For instance, as shown in Figure 2, there is the $5 \%$ damped mean response spectra for the three hazard levels at site classification IV scaled for 12-storey model. Figure 2(a) shows the spectral acceleration; Figure 2(b) shows the spectral displacement.

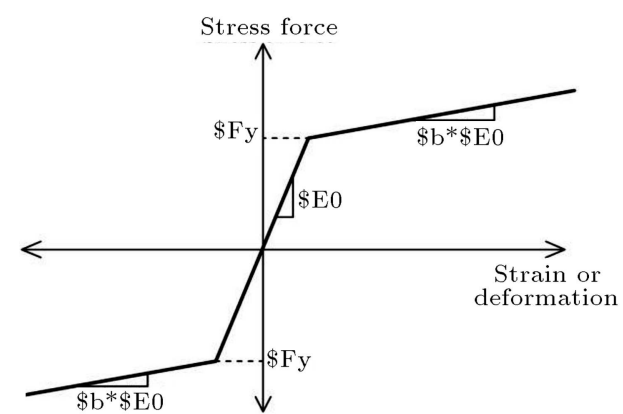

(a)

\section{Numerical analysis}

The computational model of the soil-foundationstructure systems was developed by using the OpenSees finite element software [36]. The structural members, beams, and columns were modelled as nonlinear beam-column elements using the material behaviour of steel01 with a kinematic strain hardening of $3 \%$ (Figure 3(a)). The used section for each member is the fiber section. The development of realistic numerical model of the foundation with its supporting subgrade soil was recognized as an important and

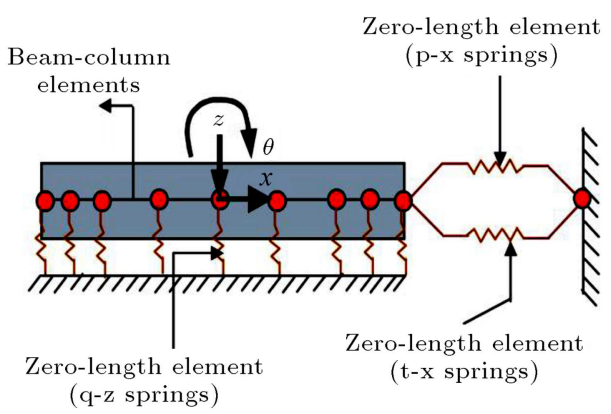

(b)

Figure 3. (a) Steel01 material for MRFs. (b) The schematic diagram of BNWF (after [36]). 


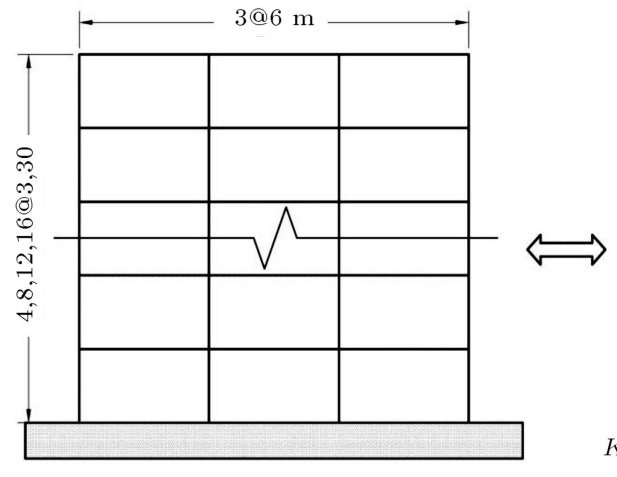

(a)

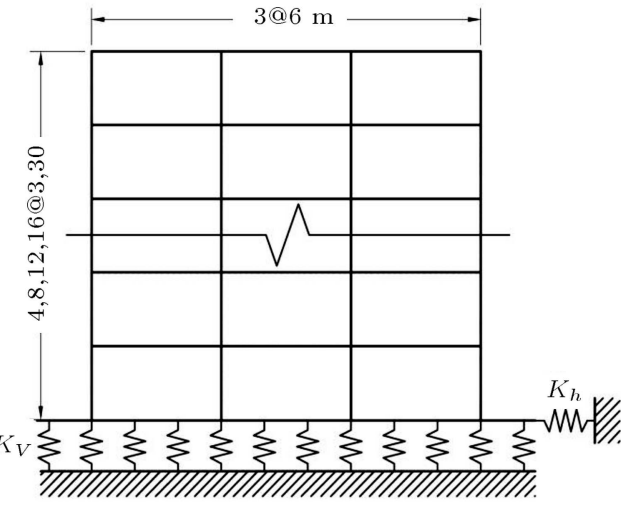

(b)

Figure 4. Different base conditions considered in the study: (a) Fixed base, and (b) nonlinear Winkler-based SSI model.

complex problem in earthquake engineering. Allotey and Naggar [37] elaborated on a Winkler-based approach utilizing multi-linear and no-tension backbone curves. Also, Harden and Hutchinson [24] developed a Winkler-based method using pile-calibrated nonlinear backbone curves of Boulanger et al. [38] to model shallow strip foundations, which can capture its rocking behaviour. The corresponding Beam-on-NonlinearWinkler-Foundation model was updated based on shallow footing load tests by Raychowdhury and Hutchinson [39] and implemented into the framework of OpenSees, as shown in Figure 3(b).

In this paper, the nonlinear response of MRF buildings is studied considering two comparative base conditions. First, rigid base condition means that the foundation system is assumed to be fixed in confronting all the movements in NSSI model (Figure 4(a)). The second is the SSI case in which foundation uplifting and soil plasticity are included, and the soil-foundation interface is modelled as nonlinear Winkler springs (Figure 4(b)). Vertical and lateral stiffness cases are selected based on recommendations by Gazetas [40], given in the following equations:

$$
\begin{aligned}
& k_{v}=\frac{G L}{1-v}\left[0.73+1.54\left(\frac{B}{L}\right)^{0.75}\right], \\
& k_{h}=\frac{G L}{2-v}\left[2+2.5\left(\frac{B}{L}\right)^{0.85}\right],
\end{aligned}
$$

where $k_{v}$ and $k_{h}$ are the vertical and lateral initial stiffness of the spring, respectively. As indicated in Section 2, $G$ is the shear modulus of the soil, $v$ is the Poisson's ratio of the soil, and $B$ and $L$ are the footing width and length, respectively. Vertical load bearing capacity was calculated after Terzaghi [41], while using foundation shape and depth factors was proposed by Meyerhof [42]. Tension capacity of the soil was assumed to be $10 \%$ of the compression capacity, $q_{u l t}$, for soil modeling. The stiffness intensity and the spring spacing along the footing length were chosen based on the study of Harden and Hutchinson [24]. A numerical study was carried out to evaluate the design parameters' effects on the buildings seismic demands, such as fundamental period, storey deflection, storey drift, base shear, and inter-storey shear. The design parameters include the SSI with three soil types and three hazard levels based on Iranian seismic code.

\section{Results and discussion}

In this section, the effects of SSI are comprehensively analyzed for multiple hazard levels on soil types II, III, and IV. Open-Sees platform is adopted to perform an eigenvalue analysis, nonlinear static pushover, and nonlinear time history analysis. The results of different cases are extracted, compared, and discussed as follows.

\subsection{Eigenvalue analysis}

The vibration period is an important parameter of a structure to estimate its seismic demand. Modern building codes generally use the period ratio (flexiblebase period, $T$, to fixed-base period, $T_{F B}$,) of buildings to assess their response to seismic loadings. Table 6 provides the vibration periods of the building models with different base conditions. Since the results of the eigenvalue analysis indicate that the fundamental periods computed from rigid base models are shorter than those of SSI models, it becomes insignificant for the higher modes. As shown in Table 6, fundamental period ratio is higher than 1.0, ranging from 1.02 to 1.07 for 4-storey model; from 1.01 to 1.07 for 8 -storey model; from 1.01 to 1.06 for 12-storey model; and from 1.01 to 1.06 for 16 -storey model. Note that as the soil stiffness decreases, fundamental period response ratio increases. It is also observed that the buildings' height has little effect on the period ratio, and can thus be neglected in evaluating the eigenvalue properties of the system. In general, Table 6 reveals that for given MRF buildings, the fundamental frequency of the soilfoundation-structure system is close to that of a fixed- 
Table 6. Vibration periods of the steel MRF models with different base conditions.

\begin{tabular}{|c|c|c|c|c|c|c|c|c|c|c|c|c|c|c|c|c|}
\hline \multirow[b]{2}{*}{ Mode } & \multicolumn{4}{|c|}{ 4-storey } & \multicolumn{4}{|c|}{ 8-storey } & \multicolumn{4}{|c|}{ 12-storey } & \multicolumn{4}{|c|}{ 16-storey } \\
\hline & $\begin{array}{l}T_{F B}{ }^{a} \\
(\mathrm{sec})\end{array}$ & $\begin{array}{c}\text { PR- } \\
\text { II }^{\mathrm{b}}\end{array}$ & $\begin{array}{l}\text { PR- } \\
\text { III }^{\mathrm{c}}\end{array}$ & $\begin{array}{l}\text { PR- } \\
\text { IV }^{\text {d }}\end{array}$ & $\begin{array}{l}T_{F B} \\
(\mathrm{sec})\end{array}$ & $\begin{array}{c}\text { PR- } \\
\text { II }\end{array}$ & $\begin{array}{c}\text { PR- } \\
\text { III }\end{array}$ & $\begin{array}{c}\text { PR- } \\
\text { IV }\end{array}$ & $\begin{array}{l}T_{F B} \\
(\text { sec) }\end{array}$ & $\begin{array}{c}\text { PR- } \\
\text { II }\end{array}$ & $\begin{array}{c}\text { PR- } \\
\text { III }\end{array}$ & $\begin{array}{c}\text { PR- } \\
\text { IV }\end{array}$ & $\begin{array}{l}T_{F B} \\
(\mathrm{sec})\end{array}$ & $\begin{array}{c}\text { PR- } \\
\text { II }\end{array}$ & $\begin{array}{c}\text { PR- } \\
\text { III }\end{array}$ & $\begin{array}{c}\text { PR- } \\
\text { IV }\end{array}$ \\
\hline 1 & 0.78 & 1.02 & 1.05 & 1.07 & 1.20 & 1.01 & 1.04 & 1.07 & 1.76 & 1.01 & 1.03 & 1.06 & 2.33 & 1.01 & 1.03 & 1.06 \\
\hline 2 & 0.23 & 1.02 & 1.03 & 1.03 & 0.41 & 1.00 & 1.02 & 1.02 & 0.60 & 1.01 & 1.02 & 1.02 & 0.77 & 1.00 & 1.01 & 1.03 \\
\hline 3 & 0.11 & 1.02 & 1.03 & 1.03 & 0.23 & 1.00 & 1.00 & 1.0 & 0.33 & 1.00 & 1.01 & 1.01 & 0.43 & 1.00 & 1.00 & 1.01 \\
\hline
\end{tabular}

base structure. Nevertheless, the flexibility introduced by the soil-foundation system will play an important role in altering the overall force and displacement demand of the buildings, as will be demonstrated later in this paper.

\subsection{Pushover analysis}

Nonlinear static analysis using pushover procedures is widely carried out in the current engineering design practice to predict the inelastic force-deformation behavior of the structure. To perform the pushover analysis, lateral loads in the form of the recommended patterns of FEMA 356 [13] were applied to the building models, followed by a displacement-controlled pushover analysis to determine the base shear-roof displacement variation for different base conditions. Figure 5 shows base shear versus the roof drift ratio (roof displacement divided by the roof elevation) for 4- and 8-storey frames. As shown in Figure 5, the SSI models present softer behavior (i.e., decrease of yield force and drift demand), indicating that the springs at the foundationsoil interface are yielding, and as a result, they modify the global stiffness of the systems. It is also observed that by decreasing the rigidity of soil, the difference between pushover curves in the fixed-base and the SSI models will be increased. The disparity in pushover curves with decreasing soil rigidity indicates that the structure-foundation system is getting softer due to the capacity mobilization of a larger number of springs. Note that the detailed seismic performance assessment of MRFs through the static nonlinear analysis by taking the SSI into account is a matter of further research. However, the objective of the present study is to provide a simple yet useful understanding of the expected behavior of the examined structures under pushover analysis.

\subsection{Time history analysis}

Following the pushover analysis, nonlinear dynamic time history analyses are carried out using the ground motion records in Table 4. Newmark linear acceleration method is used to conduct the transient analysis with solution parameters of $\gamma=0.5$ and $\beta=0.25$. A Rayleigh damping of $5 \%$ is assumed for the frame vibrating in its first and third modes as typically considered in literature for steel frame structures. Also, the modified Newton-Raphson algorithm is used, with a convergence tolerance of $1.0 \mathrm{E}-8$ over a maximum of 60 iterations, to solve the nonlinear equilibrium equations. The transformation method, which transforms the stiffness matrix by condensing out the constrained degrees of freedom, is used in the analysis as a constraint handler. This method reduces the size of the system for multi-point constraints [36].

A total of 504 time history analyses was performed (four MRF models, twenty one ground motion records, three hazard levels, and two types of base conditions). They capture both geometrical (uplift, sliding, and rocking motions) and material nonlinearities. A number of representative time history results are selected for the purpose of studying the general trend of SSI effects, as shown from Figures 6 to 16. The

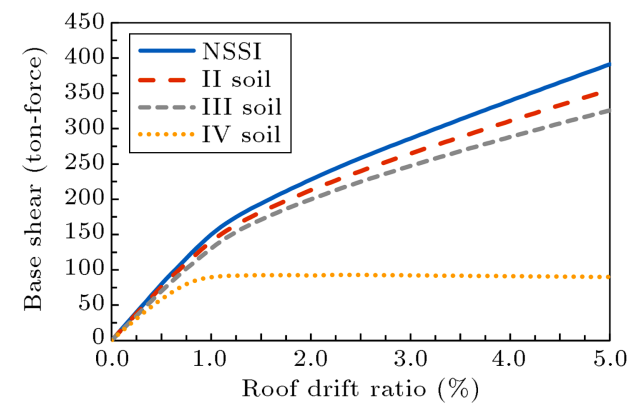

(a)

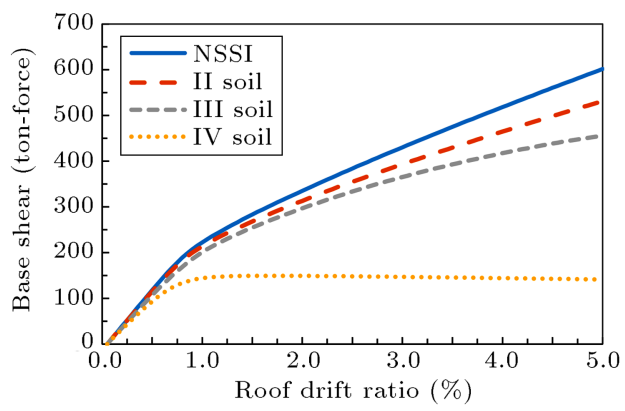

(b)

Figure 5. Base shear vs. roof drift ratio, with and without SSI: (a) 4-storey frame, and (b) 8-storey frame. 


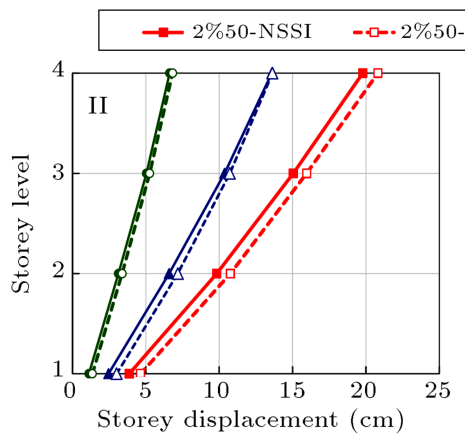

(a)

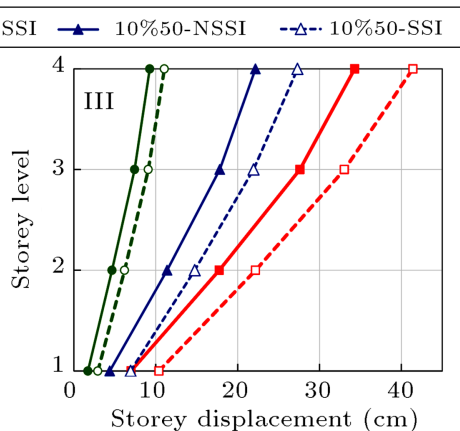

(b)

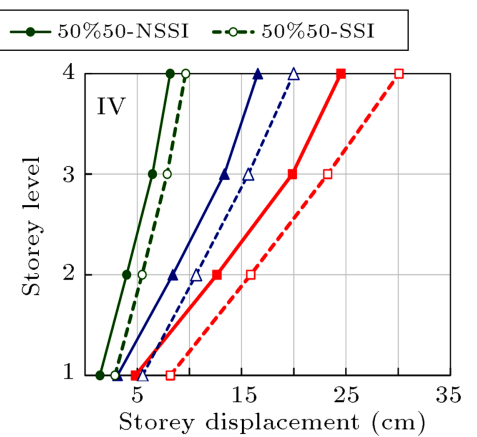

(c)

Figure 6. Storey deflection distributions of the 4-storey model for the three hazard levels at site classification: (a) II, (b) III, and (c) IV.

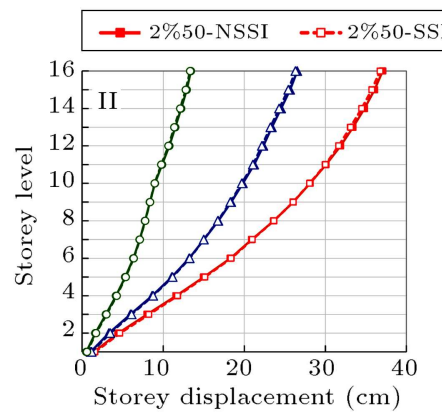

(a)

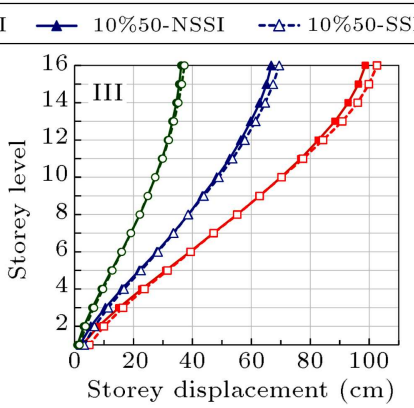

(b)

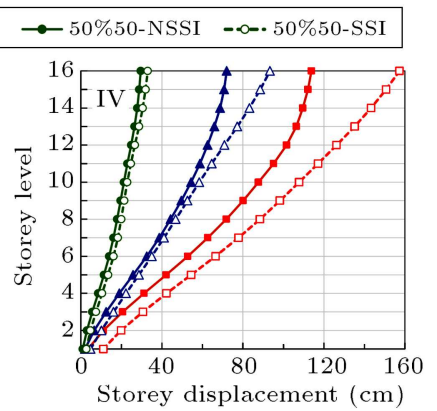

(c)

Figure 7. Storey deflection distributions of the 16-storey model for the three hazard levels at site classification: (a) II, (b) III, and (c) IV.

storey deflection, storey drift, base shear, and interstorey shear force are chosen as the most important response parameters to estimate the seismic vulnerability of a structure in design practice. For convenience, response ratio is also defined as: (peak response of structure in SSI model) / (peak response of structure in fixed-base model). The following subsections discuss the effects of subsoil rigidity and seismic intensity on inelastic seismic response of the moment-resisting frames and their performance levels. In order to reach a systematic criterion to analyze SSI effects, the average responses for each hazard level were evaluated and presented.

\subsubsection{Storey deflection}

The objective of inelastic seismic analysis method is to estimate directly and accurately the magnitude of inelastic structural deformations. The average peak absolute displacements at the floor level in the direction of applied acceleration for 4- and 16-storey frames are depicted over buildings' height in Figures 6 and 7 . It is observed that the storey displacement increases in SSI models, the displacement increases more in foundations located on soft soil, and this value is the largest one for the highest intensity motion $(2 \%$ in 50 years). As shown, storey displacement profile increases nonlinearly with the structural height. The increase in storey deflection occurs due to the overall reduction in the global stiffness resulting from the induced foundation movements. This trend of increase in displacement demand may be expected considering the displacement response spectra (see Figure 2(b)).

Figure 8(a)-(c) shows the storey deflection ratio distribution for the representative 12-storey frame. The storey deflection increases over all storeys in the SSI model, as seen in Figure 8. However, the rate of increase becomes higher for the 1 st and 2 nd storeys. It could be observed that the average response ratios of SSI-II, SSI-III, and SSI-IV reach the rates presented as follows: for $50 \%$ in 50 years hazard 1.11, 1.75, and 2.78 , respectively; for $10 \%$ in 50 years hazard $1.12,1.79$, and 2.39 , respectively; for $2 \%$ in 50 years hazard 1.12 , 1.76 , and 2.46 , respectively. It is necessary to note that lower storeys are more affected by SSI than the other storeys.

\subsubsection{Storey drift}

Storey drift ratio is the maximum relative displacement of each floor divided by the height of the same floor and is the most commonly used damage parameter. On the other hand, seismic performance is described by considering the maximum allowable damage performance for an identified seismic hazard. Having been subjected to a certain hazard, performance levels 


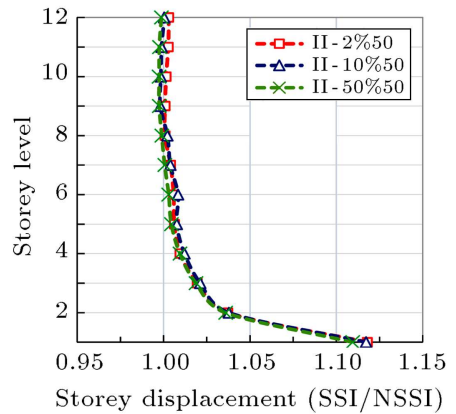

(a)

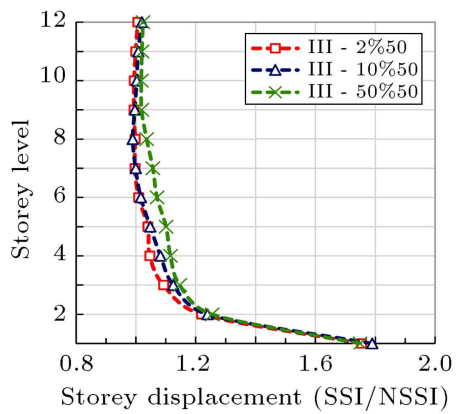

(b)

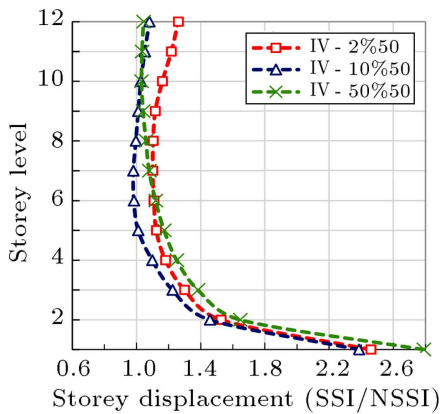

(c)

Figure 8. Storey deflection ratio distributions of the 12-storey model for the three hazard levels at site classification: (a) II, (b) III, and (c) IV.

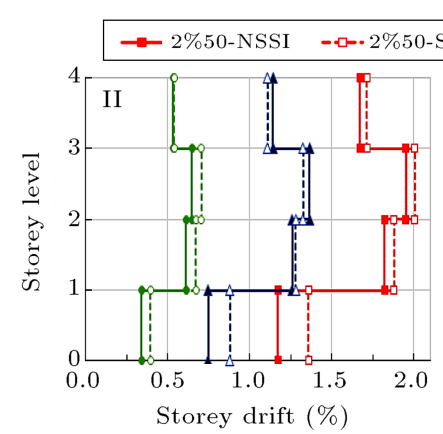

(a)

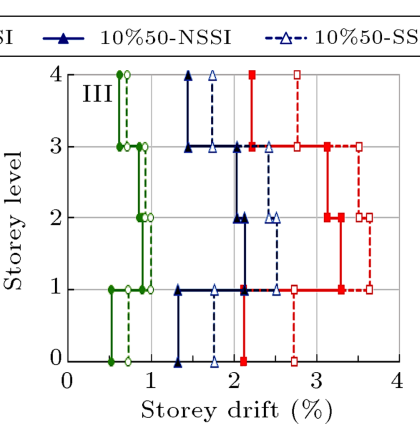

(b)

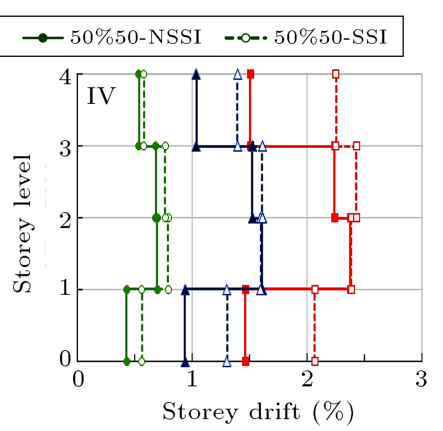

(c)

Figure 9. Storey drift ratio distributions of the 4-storey model for the three hazard levels at site classification: (a) II, (b) III, and (c) IV.

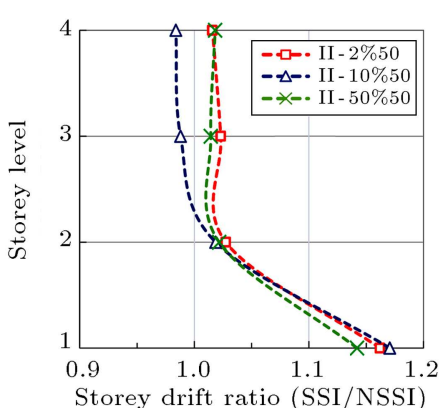

(a)

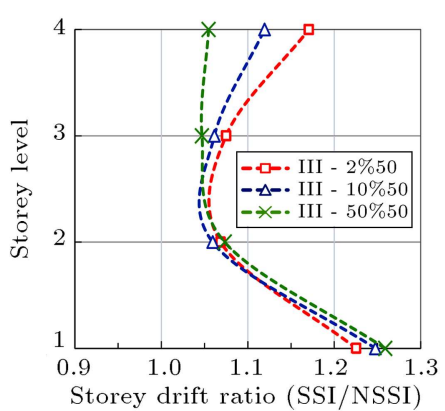

(b)

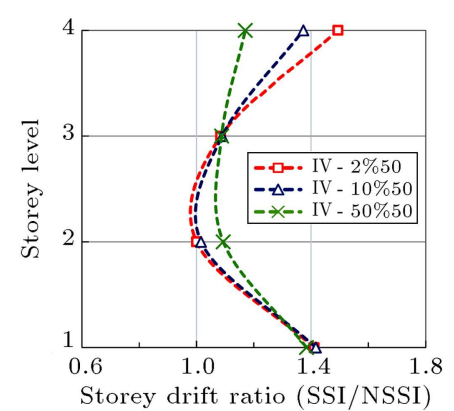

(c)

Figure 10. Storey drift ratio distributions to that of fixed-base model in the 4-storey model for the three hazard levels at site classification: (a) II, (b) III, and (c) IV.

describe the state of structures and are classified as Immediate Occupancy (IO), Life Safety (LS), and Collapse Prevention (CP) for the selected earthquake hazard levels of probability of exceedance of $50 \%$, $10 \%$, and $2 \%$ in 50 years, respectively [13]. The above-mentioned three qualitative performance levels are related to the corresponding quantitative maximum storey drift ratios of $0.7 \%, 2.5 \%$, and $5 \%$, respectively.

The storey drift ratio and the drift ratio of SSI model to that of fixed-based model over the building height are introduced in Figures 9 and 10 for 4storey building as well as in Figures 11 and 12 for 16-storey building, respectively. The seismic response demands were calculated for different hazard levels and soil conditions using average envelope of time history analyses. According to Figures 9 and 11, seismic SSI tends to increase the storey drifts in comparison to rigid base conditions. For example, the maximum average drift ratio of the fixed-based 16-storey model for $10 \%$ in 50 years ground motions is measured to be $1.1 \%, 1.8 \%$, and $2.1 \%$ for the soil types II, III, and IV, respectively, while the corresponding values for the flexible base are $1.1 \%, 2.1 \%$, and $2.6 \%$, respectively. In other words, the effects of SSI induce the increases of $0 \%, 17 \%$, and $24 \%$, respectively, in the simulated storey drifts. Furthermore, the drift amplifications for $2 \%$ in 50 years hazard level are more severe than the other levels. As a result, SSI may shift the performance level 


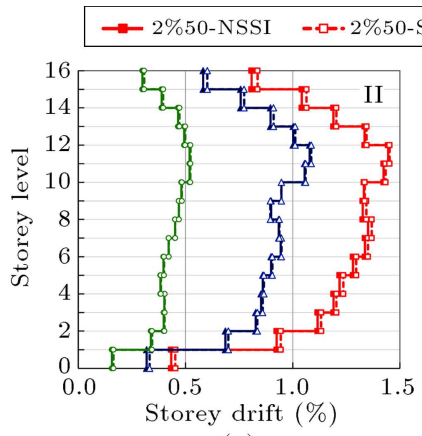

(a)

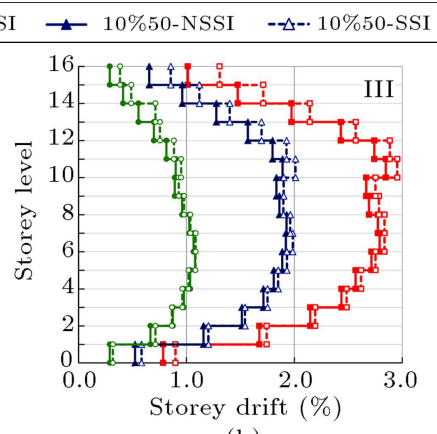

(b)

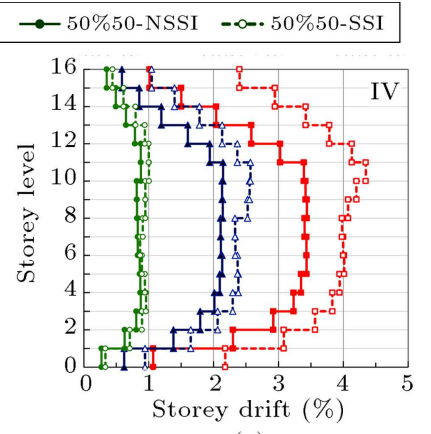

(c)

Figure 11. Storey drift ratio distributions of the 16-storey model for the three hazard levels at site classification: (a) II, (b) III, and (c) IV.

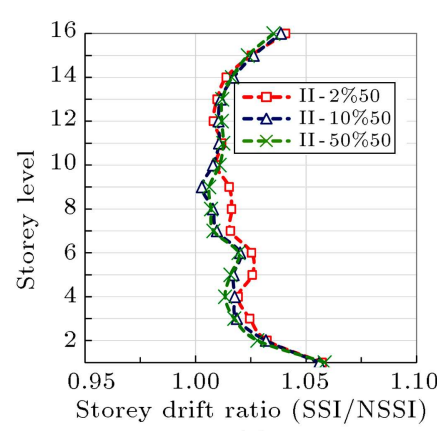

(a)

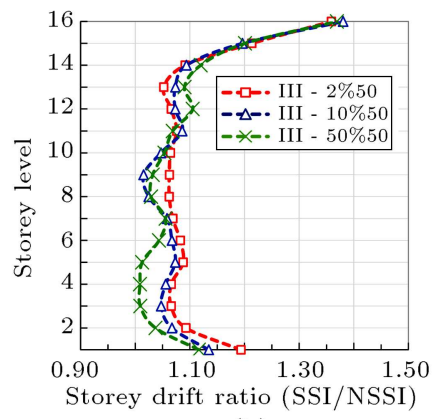

(b)

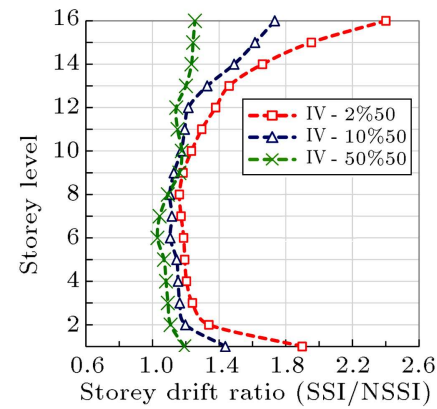

(c)

Figure 12. Storey drift ratio distributions of fixed-base model in the 16-storey model for the three hazard levels at site classification: (a) II, (b) III, and (c) IV.

of a structure from life safe zone to near collapse level.

Figure 10(a)-(c) shows the storey drift ratio response distribution over building height compared to that response value of fixed-based model for 4-storey model. The average values of SSI-II, SSI-III, and SSIIV reach the rate as follows: for $50 \%$ in 50 years hazard $1.14,1.26$, and 1.38 , respectively; for $10 \%$ in 50 years hazard $1.17,1.25$, and 1.4 , respectively; for $2 \%$ in 50 years hazard $1.16,1.22$, and 1.5 , respectively. In a similar way, Figure 12(a)-(c) shows the storey drift response ratio of 16 -storey model. The average values of SSI-II, SSI-III, and SSI-IV are: for $50 \%$ in 50 years hazard $1.06,1.37$, and 1.29 , respectively; for $10 \%$ in 50 years hazard $1.06,1.38$, and 1.75 , respectively; for $2 \%$ in 50 years hazard $1.06,1.36$, and 2.4 , respectively. As shown in Figures 10 and 12, the drift demands for flexible strip foundation increase as the underneath soil stiffness decreases. This increasing trend is more significant in the upper and lower storeys. The greatest storey drift ratio's increase occurs for the highest intensity motions ( $2 \%$ in 50 years). Also, the SSI has more significant effect on storey drift ratio as the number of storeys in the model increases. Since the drift demand is an important parameter for the design of structural members, it is very likely that the members are designed conservatively in the absence of incorporation of nonlinear SSI. Such a big difference in storey displacements and drifts is not negligible; thus, the effect of SSI must be taken into account in dynamic analyses.

It has been reported that the structure supported by deep foundation experiences less storey drifts in comparison to the structure supported by the shallow foundation due to the reduced rocking components $[43,44]$. They concluded that the choice of foundation type is dominant and should be included while investigating the influence of soil-structure interaction on the performance of mid-rise buildings sitting in soft soil. It is worth mentioning that the complexity of seismic soil-pile-structure interaction problem results in simplifying the presence of pile foundations for the structural design [45, 46]. According to Tahghighi and Konagai [46], a rational method was proposed to define a nonlinear Winkler p-y element which can model the behavior of pile group foundation subjected to lateral loading. Therefore, the proposed simplified p-y approach may conveniently be considered as a further study on the seismic behavior of building frames supported by deep foundations.

\subsubsection{Storey shear}

The seismic response of structure in terms of storey shear is selected as one of the most important response parameters in seismic design practice. Figures 13 to 16 present the average structural shear demands in comparison to rigid base conditions. The effect of SSI on the inter-storey shear profile over height was taken 


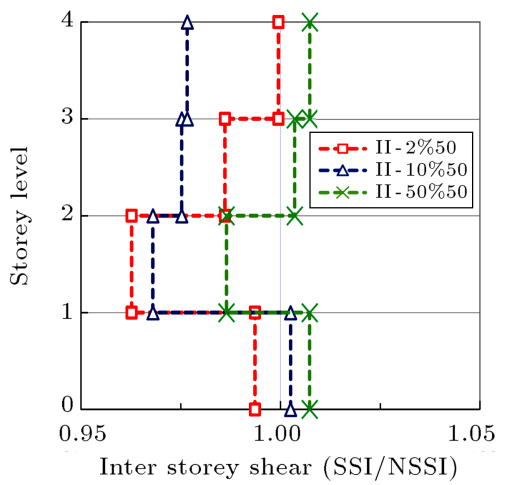

(a)

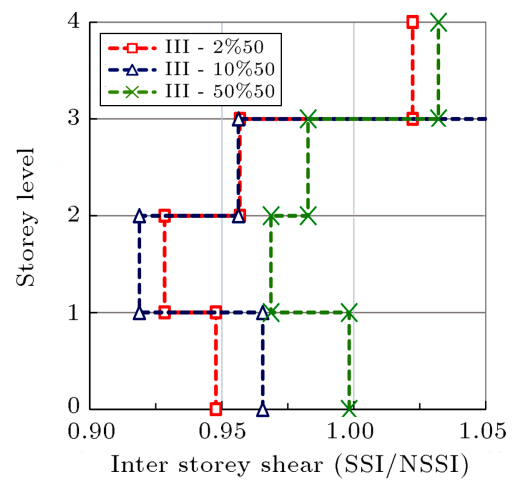

(b)

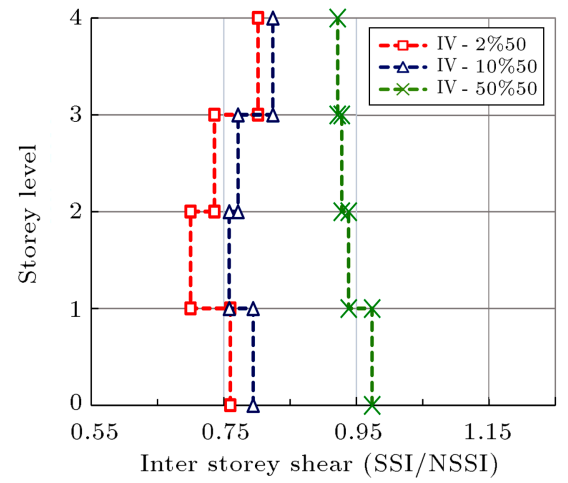

(c)

Figure 13. Storey shear ratio distributions of the 4-storey model for the three hazard levels at site classification: (a) II, (b) III, and (c) IV.

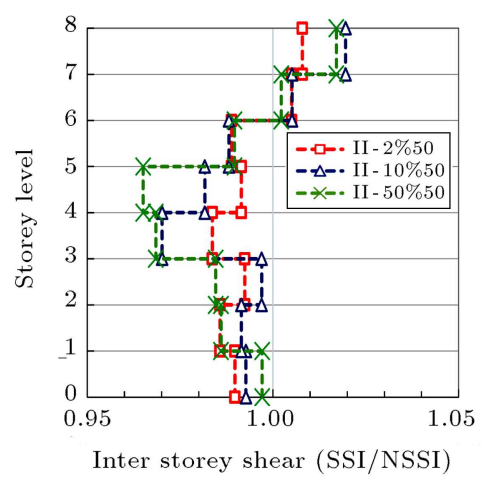

(a)

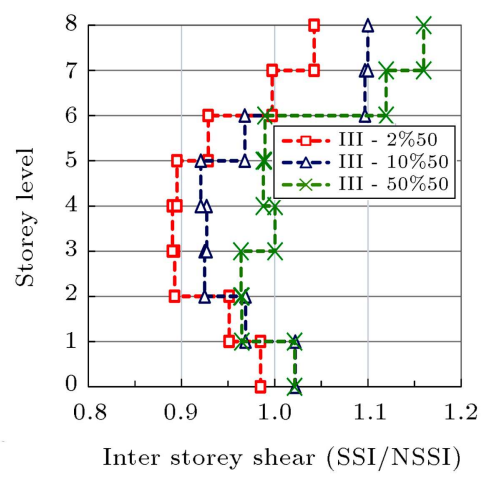

(b)

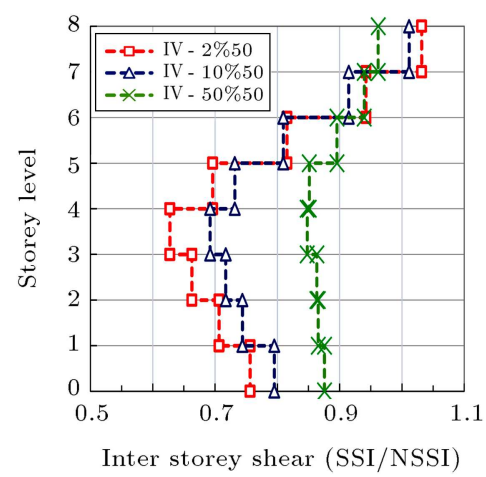

(c)

Figure 14. Storey shear ratio distributions of the 8-storey model for the three hazard levels at site classification: (a) II, (b) III, and (c) IV.

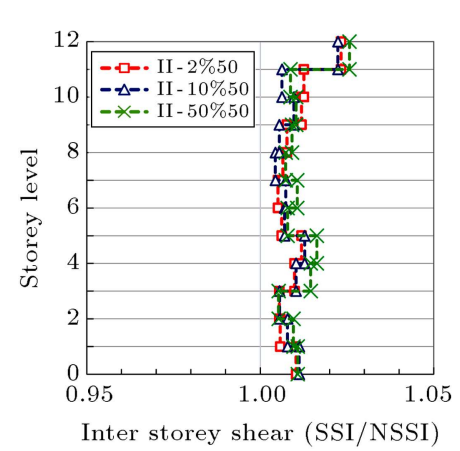

(a)

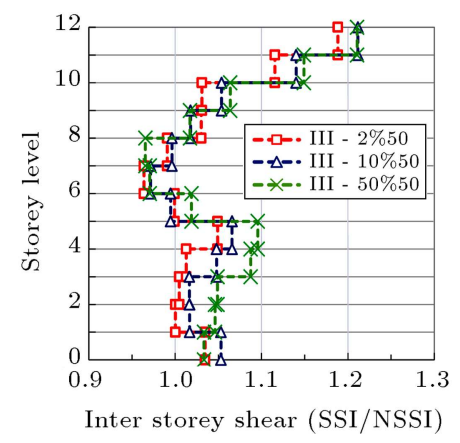

(b)

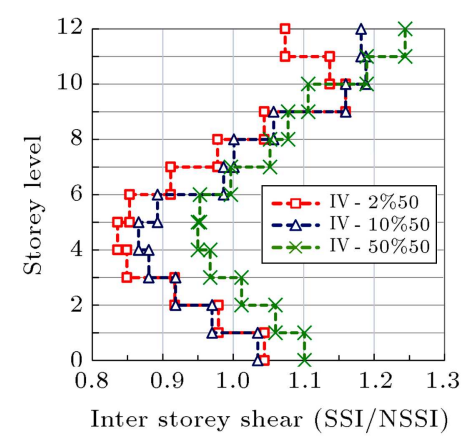

(c)

Figure 15. Storey shear ratio distributions of the 12-storey model for the three hazard levels at site classification: (a) II, (b) III, and (c) IV.

into account for all the hazard level ground motions. It could be observed that the effect of higher intensity motions ( $10 \%$ in 50 years and $2 \%$ in 50 years) can lead to the potential for greater reduction in structural shear forces due to the capacity mobilization of a larger number of mechanistic springs at the soil-foundation interface.

In Figures 13 and 14, the shear demand ratio of low-rise MRFs (i.e., 4- and 8-storey models) is almost less than one, which has good conformity to the seismic regulations such as NEHRP [10] and Standard No. 2800 [30], while the shear demands of flexiblebase are greater than rigid base conditions for the mid-rise models (i.e., 12- and 16-storey models) (see Figures 15 and 16). In addition, the peak shear at the base of the columns reduces as much as $25 \%$ for the low-rise frames, when nonlinearity is considered at the soil-foundation interface. However, for 12- and 16storey models, the peak base shear increases as much as $17 \%$ when soil flexibility is considered. Depending 


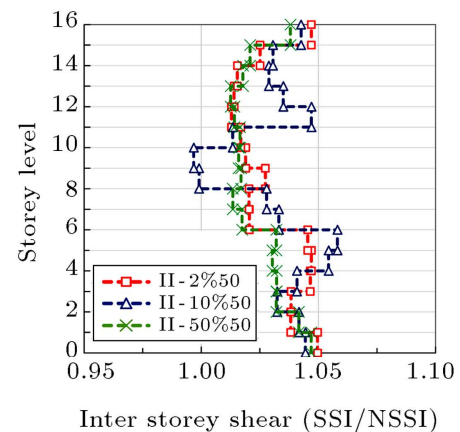

(a)

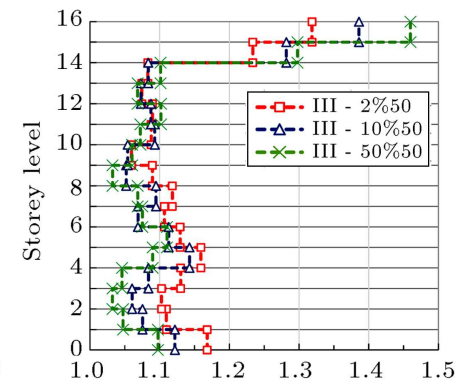

Inter storey shear (SSI/NSSI)

(b)

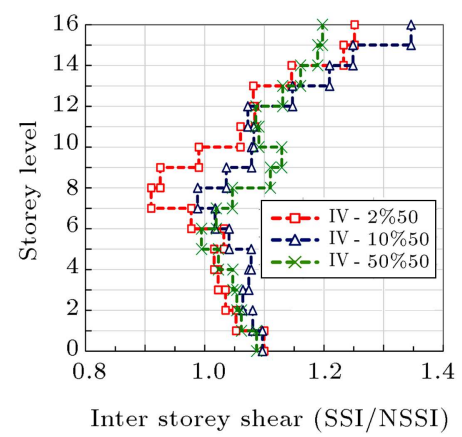

(c)

Figure 16. Storey shear ratio distributions of the 16-storey model for the three hazard levels at site classification: (a) II, (b) III, and (c) IV.

on the first result, rigid base assumption would lead to an over-conservative estimation of the base shear, especially as the soil gets softer. Depending on the second result, modeling the soil-foundation interface as fixed can exhibit an under-conservative estimation of the base shear. This implies that the change in base shear is related to the change in the chosen structure and/or ground motion. Thus, the obtained results in this article show that the earthquake response evaluation of a structure can be based on a quite different scenario from those indicated in ordinary seismic codes in which only base shear is reduced for the effect of SSI. Hence, additional work in this area of design guidelines is warranted.

\section{Concluding remarks}

In this study, the effects of seismic SSI using earthquake motions of different hazard levels were analyzed for typical shallow foundations supporting multi-storey buildings on various soil conditions. Three methods of analysis were used for seismic demands evaluation of the target MRFs. The results of the analyses include fundamental period, storey deflection, storey drift, base shear, and inter-storey shear in flexible-base and fixed-base conditions. A nonlinear Winkler-based approach was adopted for this purpose. The results were compared with those obtained from rigid base models. It was concluded that the dynamic SSI plays a considerable role in seismic behavior of low-to-mid-rise building frames including substantial increase in the lateral deflections, inter-storey drifts, and changing the performance level of the structures. If SSI is not taken into account in the analysis and design properly, the accuracy in assessing the structural safety will not be reliable while facing earthquakes. In other words, the conventional design procedures, excluding SSI, may not be adequate enough to guarantee the structural safety in building frames. Thus, it is essential to consider the SSI effects on the seismic design of regular MRFs, particularly when resting on soft soil deposit. Based on this work, the following specific conclusions are drawn:

- It is observed that the foundation flexibility has little effect on the fundamental period of MRF systems, and can thus be neglected in evaluating the eigenvalue properties of such systems;

- The obtained findings indicate that performance level of the model resting on soil type II $(375<$ $\left.V_{s}<750 \mathrm{~m} / \mathrm{s}\right)$ does not change substantially, while performance level of the model, resting on soil type III $\left(175<V_{s}<375 \mathrm{~m} / \mathrm{s}\right)$ and type IV $\left(V_{s}<175 \mathrm{~m} / \mathrm{s}\right)$, substantially increases. Thus, it is essential to consider the SSI effects on the seismic design of steel MRFs resting on soil types III and IV, particularly for high intensity earthquake motions;

- Inter-storey and base shear in the low-rise MRFs almost are reduced when nonlinearity at the soilfoundation interface is considered. But, for the midrise buildings, the shear demands are observed to increase when SSI effects are incorporated;

As mentioned, the results obtained in this article will be helpful to quantify the effects of SSI on the structural response, so that designers can be aware of the likely impact of their decisions. However, this study still needs to be verified for additional structures with a wider range of natural periods and relatively larger numbers of appropriate ground motions before the findings could be generalized and used for design recommendations. Furthermore, the choice of pile foundation may be included when investigating the effects of the soil-structure interaction on the performance of mid-rise buildings sitting in high-seismicity soft soil sites.

\section{Acknowledgments}

This study was partially supported by the University of Kashan. The first author would like to acknowledge this research sponsorship. We also thank the two anonymous reviewers for their helpful and constructive comments on the manuscript. 


\section{References}

1. Wolf, J.P., Dynamic Soil-Structure Interaction, Prentice-Hall, Englewood Cliffs, NJ (1985).

2. Kramer, S.L., Geotechnical Earthquake Engineering, Prentice-Hall, Upper Saddle River, NJ (1996).

3. Khalil, L., Sadek, M. and Shahrour, I. "Influence of the soil-structure interaction on the fundamental period of buildings", Earthquake Engineering and Structural Dynamics, 36, pp. 2445-2453 (2007).

4. Raychowdhury, P. and Hutchinson, T.C. "Performance of seismically loaded shear walls on nonlinear shallow foundations", International Journal for Numerical and Analytical Methods in Geomechanics, 35, pp. 846-858 (2011).

5. Marzban, S., Banazadeh, M. and Azarbakht, A. "Seismic performance of reinforced concrete shear wall frames considering soil-foundation-structure interaction", The Structural Design of Tall and Special Buildings, 23, pp. 302-318 (2014).

6. Arbabi, M. and Tahghighi, H. "Evaluation of soilstructure interaction effects using seismic codes", In Proceedings of the Seventh International Conference on Seismology and Earthquake Engineering (SEE7), Tehran, Iran, Paper No. 00384-SE (2015).

7. Mylonakis, G. and Gazetas, G. "Seismic soil-structure interaction: beneficial or detrimental", Journal of Earthquake Engineering, 4(3), pp. 277-301 (2000).

8. Jeremic, B., Kunnath, S. and Xiong, F. "Influence of soil-foundation- structure interaction on seismic response of the I-880 viaduct", Engineering Structures, 26, pp. 391-402 (2004).

9. Masaeli, H., Khoshnoudian, F. and Ziaei, R. "Rocking soil-structure systems subjected to near-fault pulses", Journal of Earthquake Engineering, 19(3), pp. 461-479 (2015).

10. NEHRP "Recommended seismic provisions for new buildings and other structures", FEMA P-750, Prepared by the Building Seismic Safety Council for the Federal Emergency Management Agency, Washington DC (2009).

11. ASCE 7 "Minimum design loads for buildings and other structures", ASCE/SEI 7-10, American Society of Civil Engineers/Structural Engineering Institute, Reston, VA (2010).

12. ATC 40 "Seismic evaluation and retrofit of concrete buildings", Applied Technology Council (ATC), Redwood City, CA (1996).

13. FEMA 356 "Prestandard and commentary for the seismic rehabilitation of buildings", Prepared by the American Society of Civil Engineers for the Federal Emergency Management Agency, Washington DC (2000).

14. FEMA 440 "Improvement of nonlinear static seismic analysis procedures", Prepared by the Applied Technology Council for the Federal Emergency Management Agency, Washington DC (2005).
15. ASCE 41 "Seismic rehabilitation of existing buildings", ASCE/SEI 41, American Society of Civil Engineers/Structural Engineering Institute, Reston, VA (2006).

16. Rabiee, M. "Seismic analysis of special moment frame buildings supported by shallow flexible foundations", MSc Thesis (in Persian), University of Kashan, Kashan, Iran (2015).

17. Hokmabadi, A.S., Fatahi, B. and Samali, B. "Physical modeling of seismic soil-pile-structure interaction for buildings on soft soils", International Journal of Geomechanics, 15(2) (2015). DOI: 10.1061/ (ASCE) GM.1943-5622.0000396

18. Tabatabaiefar, H.R., Fatahi, B., Ghabraie, K. and Zhou, W-H. "Evaluation of numerical procedures to determine seismic response of structures under influence of soil-structure interaction", Structural Engineering and Mechanics, 56(1), pp. 27-47 (2015).

19. Lou, M., Wang, H., Chen, X. and Zhai, Y. "Structuresoil-structure interaction: Literature review", Soil Dynamics and Earthquake Engineering, 31, pp. 17241731 (2011).

20. Tabatabaiefar, S.H.R. and Massumi, A. "A simplified method to determine seismic responses of reinforced concrete moment resisting building frames under influence of soil-structure interaction", Soil Dynamics and Earthquake Engineering, 30, pp. 1259-1267 (2010).

21. Tabatabaiefar, S.H.R., Fatahi, B. and Samali, B. "Seismic behavior of building frames considering dynamic soil-structure interaction", International Journal of Geomechanics, 13(4), pp. 409-420 (2013).

22. Fatahi, B. and Tabatabaiefar, S. "Fully nonlinear versus equivalent linear computation method for seismic analysis of midrise buildings on soft soils", International Journal of Geomechanics, 14(4), pp. 1-15 (2014).

23. Harden, C.W., Hutchinson, T.C., Martin, G.R. and Kutter, B.L. "Numerical modeling of the nonlinear cyclic response of shallow foundations", Report No. PEER-2005/04, Pacific Earthquake Engineering Research Center, University of California, Berkeley (2005).

24. Harden, C.W. and Hutchinson, T.C. "Beam-onnonlinear-Winkler-foundation modeling of shallow rocking-dominated footings", Earthquake Spectra, 25(2), pp. 277-300 (2009).

25. Gajan, S., Raychowdhury, P., Hutchinson, T.C., Kutter, B.L. and Stewart, J.P. "Application and validation of practical tools for nonlinear soil-foundation interaction analysis", Earthquake Spectra, 26(1), pp. 111-129 (2010).

26. Raychowdhury, P. "Seismic response of low-rise steel moment-resisting frame (SMRF) buildings incorporating nonlinear soil-structure interaction (SSI)", Engineering Structures, 33, pp. 958-967 (2011).

27. Rabiee, M. and Tahghighi, H. "Assessment of the soil-structure interaction effects on the seismic demands of low-rise moment-resisting frame buildings", 
In Proceedings of the Seventh International Conference on Seismology and Earthquake Engineering (SEE7), Tehran, Iran, Paper No. 081-S (2015).

28. Iranian National Building Code (part 6). "Design load for buildings", Ministry of Road, Housing and Urban Development, Tehran (2013).

29. Iranian National Building Code (part 10). "Steel structure design", Ministry of Road, Housing and Urban Development, Tehran (2013).

30. Standard No. 2800 "Iranian code of practice for seismic resistance design of buildings", 4th Edn., Ministry of Road, Housing and Urban Development, Tehran (2014).

31. Veletsos, A.S. and Meek, J.W. "Dynamic behavior of building-foundation system", Journal of Earthquake Engineering and Structural Dynamics, 3(2), pp. 121138 (1974).

32. Tehran Geotechnic Consulting Eng. "Geotechnical investigations and foundation design report of Kooh-eNoor commercial-residential complex", Final report, Shahr-e-Kord, Iran (2013a).

33. Tehran Geotechnic Consulting Eng. "Geotechnical investigations and foundation design report of Darya-yeNoor commercial-residential complex", Final report, Shahr-e-Kord, Iran (2013b).

34. PEER "Pacific Earthquake Engineering Research center strong motion database", http://peer.berkeley.edu (2015).

35. Tahghighi, H. "Seismic performance assessment of multi-story structures considering nonlinear Winklerbased soil-structure interaction model", Report on research project, Grant-in-aid for scientific research, University of Kashan, Kashan, Iran (2015).

36. OpenSees "Open system for earthquake engineering simulation", Pacific Earthquake Engineering Research (PEER) Center, http://opensees.berkeley.edu, Richmond, CA, USA (2013).

37. Allotey, N. and Naggar, M.H.E. "An investigation into the Winkler modeling of the cyclic response of rigid footings", Soil Dynamics and Earthquake Engineering, 28, pp. 44-57 (2007).

38. Boulanger, R.W., Curras, C.J., Kutter, B.L., Wilson, D.W. and Abghari, A. "Seismic soil-pile-structure interaction experiments and analyses", ASCE Journal of Geotechnical and Geoenvironmental Engineering, 125, pp. 750-9 (1999).

39. Raychowdhury, P. and Hutchinson, T.C. "Performance evaluation of a nonlinear Winkler-based shallow foundation model using centrifuge test results", Earthquake Engineering and Structural Dynamics, 38, pp. 679-698 (2009).

40. Gazetas, G. "Formulas and charts for impedances of surface and embedded foundations", Journal of
Geotechnical Engineering, 117(9), pp. 1363-1381 (1991).

41. Terzaghi, K., Theoretical Soil Mechanics, John Wiley and Sons, New York (1943).

42. Meyerhof, G.G. "Some recent research on the bearing capacity of foundations", Canadian Geotechnical Journal, 1(1), pp. 16-26 (1963).

43. Hokmabadi, A.S., Fatahi, B. and Samali, B. "Seismic response of mid-rise buildings on shallow and endbearing pile foundations in soft soil", Soils and Foundations, 54(3), pp. 345-363 (2014).

44. Hokmabadi, A.S. and Fatahi, B. "Influence of foundation type on seismic performance of buildings considering soil-structure interaction", International Journal of Structural Stability and Dynamics, 16, p. 1550043 (2016).

45. Konagai, K., Yin, Y. and Murono, Y. "Single beam analogy for describing soil-pile group interaction", Soil Dynamic and Earthquake Engineering, 23, pp. 1-9 (2003).

46. Tahghighi, H. and Konagai, K. "Numerical analysis of nonlinear soil-pile group interaction under lateral loads", Soil Dynamics and Earthquake Engineering, 27, pp. 463-474 (2007).

\section{Biographies}

Hossein Tahghighi was born in 1975. He is an Assistant Professor in the Department of Civil Engineering at University of Kashan, Kashan, Iran. He received his BSc and MSc degrees from the University of Tehran and his $\mathrm{PhD}$ degree from the University of Tokyo in Japan. He also spent more than two years in postdoctoral position at the Institute of Industrial Science, University of Tokyo. His main research area focuses on the subject of earthquake engineering, structural earthquake engineering, and geotechnical earthquake engineering.

Mehdi Rabiee was born in 1982. He is a Senior Structural Engineer at organization for development, renovation, and equipping schools of Iran. He earned his MSc degree in structural engineering from the University of Kashan in 2015. He received his BSc in Civil Engineering from Islamic Azad University of Shahr-E-Kord, Iran, in 2004. His MSc thesis is entitled "Seismic analysis of special moment frame buildings supported by shallow flexible foundations". His research interests include earthquake ground motion selection in nonlinear dynamic analysis, seismic design of concrete and steel structures, and performance-based earthquake engineering. 